\title{
Learning and teaching how to think: challenges regarding the training of qualitative researchers
}

\author{
Marta Lenise do Prado' \\ ORCID: 0000-0003-3421-3912
}

'Doctor in Nursing. Professor at UFSC. Voluntary Professor at the Post-Graduation Program in Nursing, Universidade Federal de Santa Catarina. Florianópolis, Santa Catarina, Brasil.

How to cite this article: Prado ML. Learning and teaching how to think: challenges regarding the training of qualitative researchers. Rev Bras Enferm. 2019;72(2):312-3. doi: http://dx.doi.org/10.1590/0034-7167-2018-0201
Different researchers have pointed to many different motives regarding the difficulties of the qualitative research in the field of Health. But I would like to point that, in order to strengthen the qualitative research, we need to learn and teach how to think. The need to train good qualitative researchers seems to be one of the challenges we haven't paid careful attention to, but that it now begins to take place in our discussions.

Overcoming the adversities we know so well might be a path that helps us to think how we teach qualitative research. Beyond techniques and methods, we need to understand the onto-epistemological dimensions that determine the methodological choices. There is no recipe, nor a single way of looking at the world, nor of getting close to reality. There are several paths and we should know how to choose the right one. There is no math formula and not even a recipe for that.

We all agree that new researchers need to understand that how their worldview determines the choices they make, and that their worldview is shaped by their beliefs and values, which are historically and socially built. We should understand that theories are a way to explain the world; they are provisional, historically determined and come from specific social, economic and political conditions; they are lenses each one uses to see the world; helping interpret the reality - which is mutable, partial and ephemeral.

Knowing all this provides important tools for the choices we, as researchers, need to make, but not necessarily that helps us to make them, because it is not about information but understanding. Qualitative research goes beyond applying techniques and procedures. The method has no value by itself. Devotion to method is a way to depart from an understanding of the actual experience of study participants. Methodolotry, which has been criticized by several qualitative researchers, helps us to enslave ourselves when we forget that the rules of the method serve us, but to a certain extent, because to do good qualitative research requires wisdom and confidence, imagination and creativity.

This is why we need to learn how to think. But how can we teach how to think? How can we teach how to think when we come face to face with researchers/students shaped by memorizing activities along their school years; when we are pressured by a system that demands productivity but limits the scientific production time, transforming scientists task into something pragmatic and immediatist?

How to teach how to think when the traditional teaching is still hegemonic and disregards the student as an active subject of the scientific action and of his own learning process, transforming him into a simple passive recipient of the "final" product of this activity?

We, professors, focus on the necessary material and activities proposed to the students. Wouldn't it be the case to think beyond this? We wonder: What is the use of this material? What is the use of the professor? What learning experiences might contribute to teach the young researcher how to think? Answering these questions require us to think about the meaning and reason of education. It means we need to think beyond the founding questions of qualitative research and also think about the philosophical baseline that directs our pedagogical practice to teach and learn qualitative research. 
For this, it is necessary to anchor our pedagogical practice in pedagogical references that promote reflection, sow doubt, arouse curiosity and free the imagination and creativity. We need to intentionally and consciously develop the necessary skills for a reflective teaching. To Freire ${ }^{(1)}$, a good professor is that one who challenges his students, boosting questions and critical thinking. This is why the dialogue between professor and students is a key aspect in the development of the epistemological curiosity. The dialogical relationship must be full of curiosity and restlessness. In order to develop a qualitative research, researchers must be able to think and make choices while taking full responsibility and assuming the risks regarding these choices. Beyond the theoretical-epistemological and methodological content, to prepare qualitative researchers demands a political and ethical training as well as content. Ethical researcher understood as the one capable of establishing value judgments, making decisions and taking responsibility for the choices he makes.

Therefore, the excellence of qualitative researchers requires two movements: The training of experienced researchers as critical-reflexive teachers, and the training of young researchers with broad critical-reflective skills.

Learn and teach how to think is a necessary requirement because the qualitative researcher needs to build himself with freedom of will as a foundation as well as the autonomy to organize the means of knowledge production and responsibility for his actions; being capable to create a science that contributes to the understanding the nature of the care in nursing and health but above all about the expectations of those who receive it; that recues and values creativity, the complementarity, the convergence, the complexity and unity of the subject.

\section{REFERENCE}

1. Freire P. Pedagogia da Autonomia: saberes necessários à prática educativa. 43a ed. São Paulo: Paz e Terra; 2011. 